in vivo $35: 1907-1911(2021)$

doi:10.21873/invivo.12456

Review

\title{
Robotic Total Pancreatectomy: A Narrative Review
}

\author{
KOSEI TAKAGI ${ }^{1,2}$ and BAS GROOT KOERKAMP ${ }^{2}$ \\ ${ }^{1}$ Department of Gastroenterological Surgery, Okayama University Graduate School of Medicine, \\ Dentistry, and Pharmaceutical Sciences, Okayama, Japan; \\ ${ }^{2}$ Department of Surgery, Erasmus MC Cancer Institute, \\ University Medical Center Rotterdam, Rotterdam, the Netherlands
}

\begin{abstract}
Background/Aim: Studies on robotic total pancreatectomy $(R T P)$ have been limited regardless of the increasing evidence on robotic pancreatoduodenectomy. The aim of this study was to review the current status of RTP in terms of surgical techniques and outcomes. Materials and Methods: A literature search using PubMed was conducted to investigate surgical techniques and outcomes of RTP. Results: A total of eight case series with 56 patients were included. The indications for RTP consisted of benign or premalignant tumors in 43 patients and malignant tumors in 13 patients. Surgical techniques included the "dividing technique" and "en-bloc technique". Regarding surgical outcomes, the rate of conversion to open total pancreatectomy was $3.6 \%$ and the incidence of major complications was $10.7 \%$. Conclusion: Although evidence for RTP is still lacking, RTP is feasible for selected patients when performed in specialized centers. Further studies are essential to investigate the effectiveness of RTP compared to open total pancreatectomy.
\end{abstract}

Since the recent development of minimally invasive surgery, the evidence of minimally invasive pancreatectomy has been growing $(1,2)$. However, total pancreatectomy (TP) has often been performed using an open approach due to the technical difficulties of a minimally invasive approach. Therefore, evidence of robotic total pancreatectomy (RTP) has been

This article is freely accessible online.

Correspondence to: Kosei Takagi, MD, Ph.D., Department of Gastroenterological Surgery, Okayama University Graduate School of Medicine, Dentistry, and Pharmaceutical Sciences, 2-5-1 Shikatacho, Kita-ku, Okayama 700-8558, Japan. Tel: +81 862237151, Fax: +81862218775, e-mail: kotakagi15@gmail.com

Key Words: Total pancreatectomy, robot, review. limited regardless of increasing evidence of robotic pancreatoduodenectomy (3). Moreover, no reviews on RTP have been published. Since the indication of TP has been expanded for diffuse pancreatic diseases including pancreatic ductal adenocarcinoma, intraductal papillary mucinous neoplasm, chronic pancreatitis, and pancreatic neuroendocrine tumor, the current status of RTP should be investigated. The aim of this review was to summarize surgical techniques and outcomes in patients undergoing RTP.

\section{Materials and Methods}

The present study is reported in accordance with the Preferred Reporting Items for Systematic Reviewers and Meta-Analyses (PRISMA) guidelines (4). A literature search of the PubMed was performed on $12^{\text {th }}$ of February 2021, using the keywords of robotic and total pancreatectomy. The search was limited to articles reporting on outcomes of RTP in English. After screening titles and abstracts, full-text articles were subsequently reviewed to extract the data on RTP. Records without abstracts and conference abstracts were excluded. In multiple reports with overlapping inclusion periods from the same institute, only the report with the higher number of patients was included.

\section{Results}

Overall, a literature search identified 108 articles, as depicted in Figure 1. Finally, eight case series regarding RTP were included (5-12). The characteristics of the included articles are summarized in Table I. All included studies were single-center case series from the United States $(n=5)$, Italy $(n=1)$, China $(n=1)$, and the Netherlands $(n=1)$. Regarding indications for RTP, there were 16 patients with benign tumors including chronic pancreatitis $(n=15)$ and serous cystadenoma $(n=1), 27$ patients with pre-malignant tumors including intraductal papillary mucinous neoplasm $(n=20)$ and pancreatic neuroendocrine tumor $(n=7)$, and 13 patients with malignant tumors including pancreatic ductal adenocarcinoma $(n=8)$, 


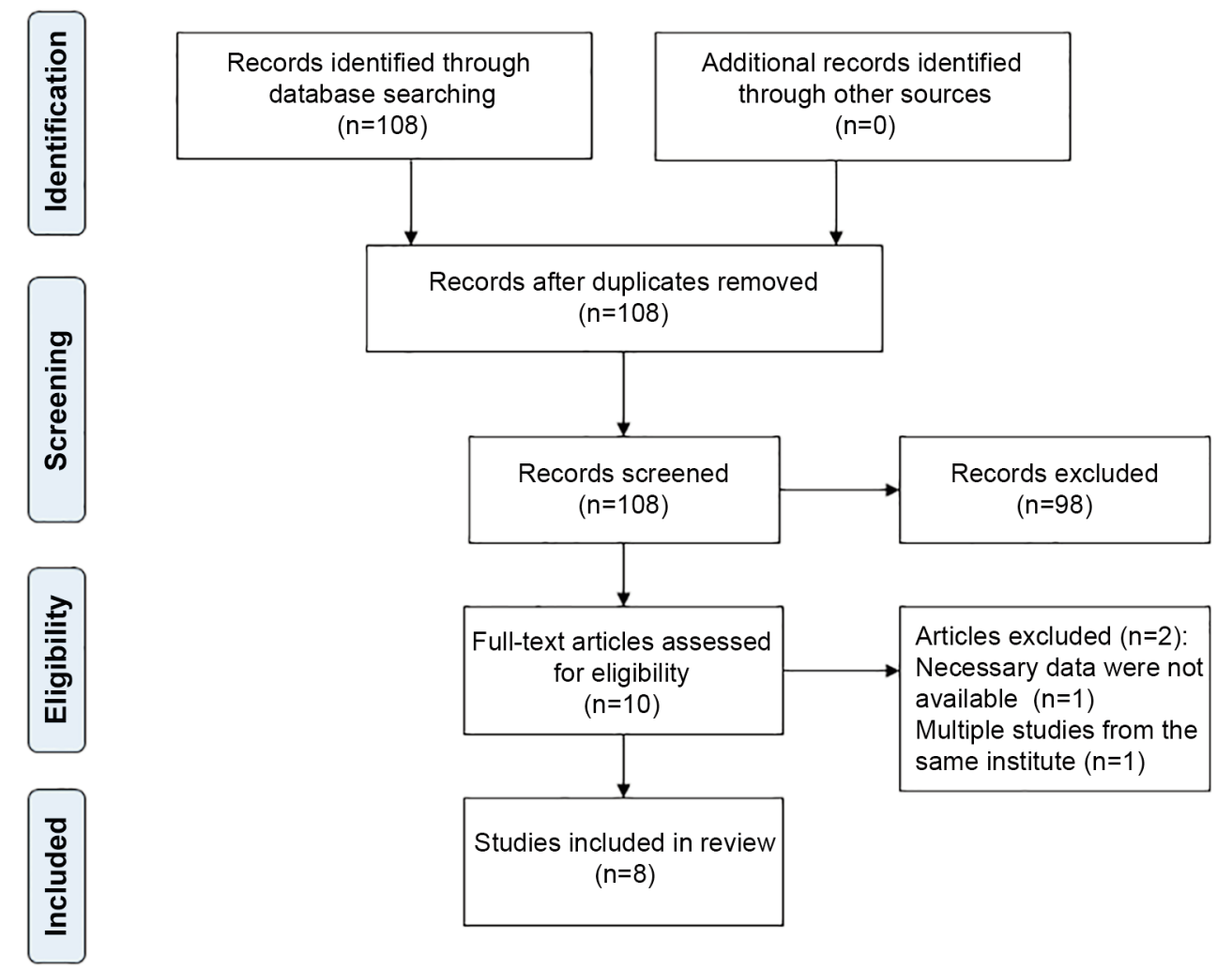

Figure 1. PRISMA 2009 flow diagram.

intraductal papillary mucinous carcinoma $(n=3)$, and renal cell carcinoma metastasis $(n=2)$.

Surgical technique of robotic total pancreatectomy. Several surgical approaches of RTP have been reported (Table I). Briefly surgical technique can be divided into "dividing technique" and "en-bloc technique".

In the dividing technique $(5,11)$, the pancreas is transected at the level of the superior mesenteric vein resulting in two specimens; the pancreatic head and the pancreatic body and tail. Thereafter, a distal pancreatectomy (DP) followed by pancreatoduodenectomy (PD) (5), or PD followed by DP (11) are performed. However, this approach is only possible if the pancreatic neck is not involved with the tumor. In addition, this approach has the potential risk of tumor spillage.

In the en-bloc technique, the traditional technique of RTP starts with the DP part. Firstly, the lower and upper border of the pancreas are dissected to mobilize the tail of the pancreas and spleen. Following splenic vessel dissection and division, full mobilization of the en-bloc pancreatic body, tail and spleen are performed. Splenic vessel preservation technique (i.e. Warschaw or Kimura technique) can be applied in spleen-preserving TP. In the en-bloc approach, the neck of the pancreas is not transected. Subsequently, PD, including the Kocher maneuver, dissection of the hepatoduodenal ligament, and the uncinate dissection, is performed. Finally, biliary and gastrointestinal reconstructions are achieved.

On the other hand, a novel technique starting with PD (the pancreatic head-first approach) followed by DP and reconstructions has been recently reported (12). In this technique, the first step with PD includes an extended Kocher's maneuver, dissection of the hepatoduodenal ligament and the superior mesenteric vein, and the detachment of the uncinate process along the superior mesenteric artery in order to mobilize the pancreatic head and duodenum completely. Again, the neck is not transected. The second step involves DP with the transection of the splenic artery and vein, and the mobilization of the pancreatic body from medial towards the pancreatic tail, followed by the dissection around the spleen. The final step is the biliary and gastrointestinal reconstruction.

Outcomes of robotic total pancreatectomy. Postoperative outcomes of case series are summarized in Table II. The mean operative time was $517 \mathrm{~min}$ (range=300-712 $\mathrm{min}$ ) and the estimated blood loss was $363 \mathrm{ml}$ (range $=100-650 \mathrm{ml}$ ). Conversion rate to open TP was $3.6 \%$ (2 cases out of 56). 
Table I. Characteristics of the reported cases subjected to robotic total pancreatectomy.

\begin{tabular}{|c|c|c|c|c|c|c|}
\hline Author & Year & Country & Study type & No. of patients & Indications & Surgical technique \\
\hline Giulianotti et al. (5) & 2011 & $\begin{array}{l}\text { United } \\
\text { States }\end{array}$ & Case series & 5 & $\begin{array}{l}\text { CP }(\mathrm{n}=1) \\
\operatorname{SC}(\mathrm{n}=1) \\
\operatorname{IPMN}(\mathrm{n}=1) \\
\operatorname{PNET}(\mathrm{n}=1) \\
\operatorname{PDAC}(\mathrm{n}=1)\end{array}$ & $\begin{array}{l}\text { Dividing technique: DP followed by PD } \\
\text { En-bloc technique: DP followed by PD }\end{array}$ \\
\hline Galvani et al. (6) & 2014 & $\begin{array}{l}\text { United } \\
\text { States }\end{array}$ & Case series & 6 & $\mathrm{CP}(\mathrm{n}=6)$ & $\begin{array}{c}\text { En-bloc technique: DP followed by PD } \\
\text { Gastrointestinal reconstruction with } \\
\text { modified Braun anastomosis } \\
\text { IAT }\end{array}$ \\
\hline Boggi et al. (7) & 2015 & Italy & $\begin{array}{l}\text { Case-match } \\
\text { study }\end{array}$ & 11 & $\begin{array}{c}\text { CP }(n=1) \\
\operatorname{IPMN}(n=5) \\
\operatorname{IPMC}(n=3) \\
\operatorname{PDAC}(n=2)\end{array}$ & $\begin{array}{l}\text { En-bloc technique: DP followed by PD } \\
\text { Biliary and gastrointestinal reconstruction }\end{array}$ \\
\hline Zureikat et al. (8) & 2015 & $\begin{array}{l}\text { United } \\
\text { States }\end{array}$ & Case series & 10 & $\begin{array}{c}\text { CP }(n=3) \\
\text { IPMN }(n=6) \\
\text { PDAC }(n=1)\end{array}$ & $\begin{array}{l}\text { En-bloc technique: } \\
\text { Laparoscopic Kocher maneuver } \\
\text { Robotic dissection of the } \\
\text { hepatoduodenal ligament } \\
\text { DP followed by PD with or without IAT } \\
\text { Biliary and gastrointestinal reconstruction }\end{array}$ \\
\hline $\begin{array}{l}\text { Konstantinidis } \\
\text { et al. (9) }\end{array}$ & 2018 & $\begin{array}{l}\text { United } \\
\text { States }\end{array}$ & Case report & 1 & IPMN (n=1) & $\begin{array}{l}\text { En-bloc technique: DP followed by PD } \\
\text { Biliary and gastrointestinal reconstruction }\end{array}$ \\
\hline $\begin{array}{l}\text { de Mesquita Neto } \\
\text { et al. (10) }\end{array}$ & 2018 & $\begin{array}{l}\text { United } \\
\text { States }\end{array}$ & Case series & 7 & $\begin{array}{l}\text { CP }(n=1) \\
\text { IPMN }(n=4) \\
\text { PNET }(n=2)\end{array}$ & $\begin{array}{l}\text { En-bloc technique: DP followed by PD } \\
\text { Biliary and gastrointestinal reconstruction }\end{array}$ \\
\hline Weng et al. (11) & 2020 & China & PSM & 15 & $\begin{array}{l}\text { CP }(n=3) \\
\text { IPMN }(n=3) \\
\operatorname{PNET~}(n=3) \\
\operatorname{PDAC~}(n=4) \\
\operatorname{RCC}(n=2)\end{array}$ & $\begin{array}{l}\text { Dividing technique: PD followed by DP } \\
\text { En-bloc technique: Kocher maneuver, } \\
\text { and DP followed by PD } \\
\text { Biliary and gastrointestinal reconstruction }\end{array}$ \\
\hline Takagi et al. (12) & 2021 & Netherlands & Case report & 1 & PNET $(\mathrm{n}=1)$ & $\begin{array}{l}\text { En-bloc technique: PD-first, followed by DP } \\
\text { Biliary and gastrointestinal reconstruction }\end{array}$ \\
\hline
\end{tabular}

CP: Chronic pancreatitis; SC: serous cystadenoma; IPMN: intraductal papillary mucinous neoplasm; IPMC: intraductal papillary mucinous carcinoma; PNET: pancreatic neuroendocrine tumor; PDAC: pancreatic ductal adenocarcinoma; RCC: renal cell carcinoma metastasis; DP: distal pancreatectomy; PD: pancreatoduodenectomy; IAT: islet-cell autotransplantation; PSM: propensity score matching.

The overall incidences of reoperation and major complications were $5.4 \%$ (3 out of 56 ) and $10.7 \%$ (6 out of $56)$, respectively. The mean postoperative hospital stay was 13 days (range $=7-27$ days).

Two studies compared outcomes of RTP to open TP. Boggi et al. (7) performed a case-matched study comparing RTP $(\mathrm{n}=11)$ with open TP $(\mathrm{n}=11)$. Operative time was significantly longer in RTP (600 min vs. $469 \mathrm{~min}, p=0.014$ ), however, blood loss was significantly decreased $(220 \mathrm{ml} v s .705 \mathrm{ml}$, $p=0.004)$. Postoperative outcomes and recovery measures did not differ significantly between the groups, showing the feasibility of RTP in selected patients. In another study by Weng et al. (11), a propensity score matching between RTP $(\mathrm{n}=15)$ and open TP $(\mathrm{n}=15)$ demonstrated significantly decreased operative time (300 $\mathrm{min} v s .360 \mathrm{~min}, p=0.03$ ), and high en-bloc resection rate $(73 \%$ vs. $40 \%, p=0.14)$ in RTP. Both RTP and open TP groups had comparable postoperative outcomes (major complications: $6.7 \%$ vs. $26.7 \%, p=0.33$; mortality: $0 \%$ vs. $6.7 \%, p=1.0$ ) and quality of life on exocrine and endocrine insufficiency.

\section{Discussion}

This review is the first to highlight surgical techniques and outcomes in RTP, summarizing the current literature on RTP. To date, only eight case series have been reported on the feasibility of RTP. The use of a minimally invasive approach for TP could be associated with better postoperative outcomes such as decreased blood loss and shorter hospital stay. However, the majority of the available data on the potential benefits of RTP is based on small single center studies. Therefore, it remains unclear whether RTP decreases the complication rates and provides significant benefits justifying the additional costs of the robotic approach. To overcome these issues, further studies with larger volumes are needed. 
Table II. Outcomes of robotic total pancreatectomy.

\begin{tabular}{|c|c|c|c|c|c|c|c|c|c|}
\hline Author & $\begin{array}{l}\text { No. of } \\
\text { patients }\end{array}$ & $\begin{array}{l}\text { Operative } \\
\text { time (min) }\end{array}$ & $\begin{array}{c}\text { Blood } \\
\text { loss (ml) }\end{array}$ & Conversion & Reoperation & $\begin{array}{l}\text { Major } \\
\text { morbidity }\end{array}$ & Mortality & $\begin{array}{c}\text { Hospital } \\
\text { stay (days) }\end{array}$ & $\begin{array}{l}\text { Comparison with } \\
\text { other procedure } \\
\text { (numbers) }\end{array}$ \\
\hline $\begin{array}{l}\text { Giulianotti } \\
\text { et al. (5) }\end{array}$ & 5 & $\begin{array}{c}480 \\
(300-560)\end{array}$ & $\begin{array}{c}300 \\
(50-650)\end{array}$ & 0 & 0 & 0 & 0 & $7(5-10)$ & NA \\
\hline $\begin{array}{l}\text { Galvani } \\
\text { et al. (6) }\end{array}$ & 6 & $\begin{array}{c}712 \\
(612-835)\end{array}$ & $\begin{array}{c}630 \\
(500-800)\end{array}$ & 0 & 0 & 0 & 0 & $12(11-14)$ & NA \\
\hline $\begin{array}{l}\text { Boggi } \\
\text { et al. (7) }\end{array}$ & 11 & $\begin{array}{c}600 \\
(400-800)\end{array}$ & $\begin{array}{c}220 \\
(100-450)\end{array}$ & 0 & $1(9 \%)$ & $2(18 \%)$ & 0 & $27(12-88)$ & $\begin{array}{c}\text { RTP (11) } \\
v s . \text { OTP (11) }\end{array}$ \\
\hline $\begin{array}{l}\text { Zureikat } \\
\text { et al. }(8)\end{array}$ & 10 & $\begin{array}{c}560 \\
(461-592)\end{array}$ & $\begin{array}{c}650 \\
(400-1,000)\end{array}$ & 1 & $1(10 \%)$ & $2(20 \%)$ & 0 & $10(7-10)$ & NA \\
\hline $\begin{array}{l}\text { Konstantinidis } \\
\text { et al. (9) }\end{array}$ & 1 & NA & NA & 0 & 0 & 0 & 0 & 9 & $\begin{array}{c}\text { NCDB review: } \\
\text { RTP (73), LTP }(455) \\
\text { vs. OTP }(3348)\end{array}$ \\
\hline $\begin{array}{l}\text { de Mesquita } \\
\text { Neto et al. (10) }\end{array}$ & 7 & $\begin{array}{c}480 \\
(330-660)\end{array}$ & $\begin{array}{c}240 \\
(50-400)\end{array}$ & 1 & 1 & 1 & 0 & $10(7-14)$ & NA \\
\hline $\begin{array}{l}\text { Weng et al. } \\
\text { (11) }\end{array}$ & 15 & $\begin{array}{c}300 \\
(250-360)\end{array}$ & $\begin{array}{c}400 \\
(200-700)\end{array}$ & 0 & 0 & $1(7 \%)$ & 0 & 18 & $\begin{array}{c}\text { RTP (15) } \\
v s . \text { OTP (78) }\end{array}$ \\
\hline $\begin{array}{l}\text { Takagi } \\
\text { et al. (12) }\end{array}$ & 1 & 490 & 100 & 0 & 0 & 0 & 0 & 10 & NA \\
\hline
\end{tabular}

NA: Not assessed; RTP: robotic total pancreatectomy; LTP: laparoscopic total pancreatectomy; OTP: open total pancreatectomy; NCDB: National Cancer Database.

The outcomes of RTP from eight case series involving 56 patients were acceptable, with a conversion rate to open procedure of $3.6 \%$ and a major complication rate of $10.7 \%$. Furthermore, a study by Konstantinidis et al. (9) demonstrated the outcomes of RTP $(n=73)$ compared to laparoscopic $(n=455)$ and open TP $(n=3348)$ between 2010 and 2014 using the National Cancer Database (NCDB) in the United States. The results showed that minimally invasive TP was associated with shorter hospital stay and reduced mortality compared to open TP. Clinicopathological factors including negative margin rates and retrieved lymph nodes were found to be similar between the groups. Moreover, the median overall survival for pancreatic ductal adenocarcinoma was similar between robotic, laparoscopic, and open TP (22.5 vs. 22.4 vs. 20.0 months, $p=0.22$ ). Although a randomized controlled trial comparing robotic, laparoscopic, and open TP appears infeasible, highlevel evidence supporting the benefits of RTP should be investigated in large international multicenter studies.

The Miami international evidence-based guidelines on minimally invasive pancreas resection have been recently published (1), however there have been no recommendations on performing minimally invasive TP. Based on our findings, the feasibility of RTP has been demonstrated, however, the safety should be confirmed in larger series.

With respect to technical aspects, RTP is a complex and challenging procedure, requiring advanced skills and experiences with both pancreatic and robotic surgery. However, TP is the combination of PD and DP. Therefore, RTP should be performed after achieving extensive experience with robotic PD and DP. It has been reported that high-volume centers have improved postoperative outcomes following minimally invasive pancreas resection $(13,14)$, Therefore, RTP should be performed in selected high-volume centers.

With respect to surgical techniques of RTP, the en-bloc technique has the potential benefit of reducing the risk of tumor spillage in patients with malignant diseases. In the en-bloc technique, the potential advantages using the pancreatic headfirst approach have been suggested (12), however no comparative studies have been reported so far regarding the surgical techniques in RTP. In contrast, due to the limited space in the intraabdominal cavity, the dividing technique might be easier compared to the management of the large specimen consisting of the whole pancreas and the spleen in the en-bloc approach. Accordingly, surgical techniques should be selected according to the surgeons' experience and patients' diseases.

There are a few limitations to this study. The included studies are all case series with small sample size from single centers. Furthermore, well designed studies with or without randomization are lacking. Surgeon experience, training, and available resources should be considered to determine which approach can be adopted. Prospective national registration should be employed to monitor the outcomes as well as to improve the quality of evidence on this topic.

\section{Conclusion}

The present review represents the current status of RTP in terms of surgical techniques and outcomes. RTP in selected 
patients can be an appropriate alternative to open TP. Although the evidence of RTP remains limited, the feasibility has been demonstrated with improved postoperative outcomes compared to open TP. Further large studies should be conducted to prove the safety and superiority of RTP.

\section{Conflicts of Interest}

The Authors declare that they have no conflicts of interest regarding this study.

\section{Authors' Contributions}

K.T. contributed to the study conception and design, the acquisition of data, the development of the protocol, and the drafting of the manuscript. B.G.K. contributed to the development of the protocol and the critical revision of the final draft. All Authors have approved the final version.

\section{Acknowledgements}

Financial support was received from Japan Society for the Promotion of Science (JSPS KAKENHI Grant Number JP 21K16447).

\section{References}

1 Asbun HJ, Moekotte AL, Vissers FL, Kunzler F, Cipriani F, Alseidi A, D’Angelica MI, Balduzzi A, Bassi C, Björnsson B, Boggi U, Callery MP, Del Chiaro M, Coimbra FJ, Conrad C, Cook A, Coppola A, Dervenis C, Dokmak S, Edil BH, Edwin B, Giulianotti PC, Han HS, Hansen PD, van der Heijde N, van Hilst J, Hester CA, Hogg ME, Jarufe N, Jeyarajah DR, Keck T, Kim SC, Khatkov IE, Kokudo N, Kooby DA, Korrel M, de Leon FJ, Lluis N, Lof S, Machado MA, Demartines N, Martinie JB, Merchant NB, Molenaar IQ, Moravek C, Mou YP, Nakamura M, Nealon WH, Palanivelu C, Pessaux P, Pitt HA, Polanco PM, Primrose JN, Rawashdeh A, Sanford DE, Senthilnathan P, Shrikhande SV, Stauffer JA, Takaori K, Talamonti MS, Tang CN, Vollmer CM, Wakabayashi G, Walsh RM, Wang SE, Zinner MJ, Wolfgang CL, Zureikat AH, Zwart MJ, Conlon KC, Kendrick ML, Zeh HJ, Hilal MA, Besselink MG and International Study Group on Minimally Invasive Pancreas Surgery (I-MIPS): The Miami international evidence-based guidelines on minimally invasive pancreas resection. Ann Surg 271(1): 1-14, 2020. PMID: 31567509. DOI: 10.1097/SLA.0000000000003590

2 Beane JD, Borrebach JD, Zureikat AH, Kilbane EM, Thompson VM and Pitt HA: Optimal pancreatic surgery: are we making progress in North America? Ann Surg, 2019. PMID: 31663969. DOI: $10.1097 /$ SLA .0000000000003628

3 Zwart MJW, Nota CLM, de Rooij T, van Hilst J, Te Riele WW, van Santvoort HC, Hagendoorn J, Rinkes IHMB, van Dam JL, Latenstein AEJ, Takagi K, Tran TCK, Schreinemakers J, van der Schelling G, Wijsman JH, Festen S, Daams F, Luyer MD, de Hingh IHJT, Mieog JSD, Bonsing BA, Lips DJ, Hilal MA, Busch OR, Saint-Marc O, Zeh HJ 3rd, Zureikat AH, Hogg ME, Molenaar IQ, Besselink MG, Koerkamp BG and Dutch Pancreatic Cancer Group: Outcomes of a multicenter training program in robotic pancreatoduodenectomy (LAELAPS-3). Ann
Surg, 2021. PMID: 33534227. DOI: 10.1097/SLA.00000000 00004783

4 Moher D, Liberati A, Tetzlaff J, Altman DG and PRISMA Group: Preferred reporting items for systematic reviews and meta-analyses: the PRISMA statement. BMJ 339: b2535, 2009. PMID: 19622551. DOI: 10.1136/bmj.b2535

5 Giulianotti PC, Addeo P, Buchs NC, Bianco FM and Ayloo SM: Early experience with robotic total pancreatectomy. Pancreas 40(2): 311-313, 2011. PMID: 21311310. DOI: 10.1097/MPA. 0b013e3181f7e303

6 Galvani CA, Rodriguez Rilo H, Samamé J, Porubsky M, Rana A and Gruessner RW: Fully robotic-assisted technique for total pancreatectomy with an autologous islet transplant in chronic pancreatitis patients: results of a first series. J Am Coll Surg 218(3): e73-e78, 2014. PMID: 24559970. DOI: 10.1016/ j.jamcollsurg.2013.12.006

7 Boggi U, Palladino S, Massimetti G, Vistoli F, Caniglia F, De Lio N, Perrone V, Barbarello L, Belluomini M, Signori S, Amorese G and Mosca F: Laparoscopic robot-assisted versus open total pancreatectomy: a case-matched study. Surg Endosc 29(6): 1425-1432, 2015. PMID: 25159652. DOI: 10.1007/s004 64-014-3819-9

8 Zureikat AH, Nguyen T, Boone BA, Wijkstrom M, Hogg ME, Humar A and Zeh H 3rd: Robotic total pancreatectomy with or without autologous islet cell transplantation: replication of an open technique through a minimal access approach. Surg Endosc 29(1): 176-183, 2015. PMID: 25005012. DOI: 10.1007/s00464014-3656-x

9 Konstantinidis IT, Jutric Z, Eng OS, Warner SG, Melstrom LG, Fong Y, Lee B and Singh G: Robotic total pancreatectomy with splenectomy: technique and outcomes. Surg Endosc 32(8): 36913696, 2018. PMID: 29273875. DOI: 10.1007/s00464-017-6003-1

10 de Mesquita Neto JWB, Macedo FI, Liu Y and Yiengpruksawan A: Fully robotic total pancreatectomy: technical aspects and outcomes. J Robot Surg 13(1): 77-82, 2019. PMID: 29713931. DOI: $10.1007 / \mathrm{s} 11701-018-0818-1$

11 Weng Y, Chen M, Gemenetzis G, Shi Y, Ying X, Deng X, Peng $\mathrm{C}$, Jin J and Shen B: Robotic-assisted versus open total pancreatectomy: a propensity score-matched study. Hepatobiliary Surg Nutr 9(6): 759-770, 2020. PMID: 33299830. DOI: $10.21037 / \mathrm{hbsn} .2020 .03 .19$

12 Takagi K and Koerkamp BG: Robotic total pancreatectomy: a novel pancreatic head-first approach (with Video). J Gastrointest Surg, 2021. PMID: 33570722. DOI: 10.1007/s11605-021-04922-5

13 Adam MA, Thomas S, Youngwirth L, Pappas T, Roman SA and Sosa JA: Defining a hospital volume threshold for minimally invasive pancreaticoduodenectomy in the United States. JAMA Surg 152(4): 336-342, 2017. PMID: 28030713. DOI: 10.1001/jamasurg.2016.4753

14 Torphy RJ, Friedman C, Halpern A, Chapman BC, Ahrendt SS, McCarter MM, Edil BH, Schulick RD and Gleisner A: Comparing short-term and oncologic outcomes of minimally invasive versus open pancreaticoduodenectomy across low and high volume centers. Ann Surg 270(6): 1147-1155, 2019. PMID: 29771723. DOI: 10.1097/SLA.0000000000002810

Received March 10, 2021

Revised April 12, 2021 Accepted April 13, 2021 